\title{
Significance of Cell Wall Structures on Yeast Classification: Proton Magnetic Resonance and Serological and Deoxyribonucleic Acid Characterization of Candida sake and Related Species
}

\author{
Y. FUKAZAWA, T. NAKASE, T. SHINODA, A. NISHIKAWA, K. KAGAYA, AND T. TSUCHIYA \\ Department of Microbiology, Meiji College of Pharmacy, Tokyo 154, Jàpan, and Research Institute for Life \\ Sciences, Ajinomoto Co., Inc., Yokohama 244, Japan
}

\begin{abstract}
The serological properties and patterns of proton magnetic resonance spectra of cell wall mannans were characterized in 15 strains of Candida sake including the previous taxa $C$. tropicalis var. lambica, C. maltosa, C. vanriji, $C$. salmonicola, $C$. cloacae, $C$. parapsilosis var. intermedia, and $C$. natalensis. The proton magnetic resonance spectra of the mannans were divided into four patternographic types. Serological analyses also demonstrated a division into four serotypes that corresponded to the four proton magnetic resonance spectral types. Antigenic patterns of groups I and II closely resembled those of $C$. tropicalis and C. subtropicalis, respectively; strains of group III were related to both $C$. parapsilosis and S. cerevisiae; and strains of group IV were closely related to $S$. cerevisiae. The guanine plus cytosine contents of the deoxyribonucleic acid of group I and group II strains were heterogeneous, whereas strains of groups III and IV showed guanine plus cytosine values with narrow ranges within each group. These data suggest that the four groupings represent at least four species.
\end{abstract}

The recent monograph on yeast taxonomy by Lodder (8) places Torulopsis sake and several species of Candida together as one species, Candida sake. Morphology and growth characteristics, as well as biochemical properties reflecting intermediate metabolism, were taken into consideration.

Recently, Gorin and Spencer (7) and Nakase and Komagata (15) suggested a heterogeneity in strains of $C$. sake on the basis of the guanine plus cytosine $(G+C)$ content of their respective deoxyribonucleic acids (DNAs). Also, Phaff et al. (17) have pointed out that strains of $C$. sake can be divided into a number of physiological types. More recently, Nakase (12) divided this species into five groups, based on DNA base composition patterns and proton magnetic resonance (PMR) spectra of alkali-extracted mannans. On the other hand, Tsuchiya et al. (21-23) studied the serological characteristics of various yeasts and suggested that serological relationships may furnish the most valuable criterion for yeast taxonomy. They reported that $C$. sake and C. tropicalis were closely related serologically.

In this report we characterize the members of C. sake mainly from the point of view of their serological characteristics and the PMR spectra of alkali-extracted mannans. We show that the two methods give concordant results and that they correlate with classification based on analysis of DNA base composition in several instances. A taxonomic system is developed from these criteria.

\section{MATERIALS AND METHODS}

Strains used. The strains of $C$. sake used as antigens for serological tests and for PMR spectra are listed in Table 1 together with sources from which they were obtained.

Biological characteristics. Taxonomic characteristics were examined by the methods of Wickerham (24) and of Lodder (8).

Determination of DNA base composition. DNAs were isolated and purified as reported previously (14, 16). The DNA base composition was calculated from the thermal denaturation temperature by the formula of Marmur and Doty (10). The thermal denaturation temperature was measured by the method of Yamada and Komagata (25).

Extraction and purification of polysaccharide. Yeast cells grown on Sabouraud medium for $48 \mathrm{~h}$ were harvested, washed three times with distilled water, and heated at $100 \mathrm{C}$ for $2 \mathrm{~h}$. After centrifugation, the cells were suspended in 5 volumes of $2 \%$ aqueous potassium hydroxide solution and extracted for $2 \mathrm{~h}$ at $100 \mathrm{C}$. The succeeding extraction and purification of polysaccharide were by the methods of Gorin and Spencer (6).

Determination of PMR spectrum of polysaccharide. PMR spectra were determined with $20 \%$ solutions of polysaccharide in deuterium oxide at $70 \mathrm{C} \mathrm{(6)}$ with a JEOR $100-\mathrm{MHz}$ nuclear magnetic resonance spectrometer (Japan Electron Optics, Tokyo) in 
TABLE 1. Sources of strains of Candida sake and related species

\begin{tabular}{|c|c|c|c|}
\hline Group & & Strain & Source \\
\hline I & $\begin{array}{l}\text { C. sake } \\
\text { C. sake } \\
\text { C. sake } \\
\text { C. sake } \\
\text { C. sake } \\
\text { C. tropicalisc } \\
\text { C. albicans }\end{array}$ & $\begin{array}{l}\text { AJ }^{a} 5146^{b} \\
\text { AJ } 14288 \text { (C. vanriji) } \\
\text { AJ } 4755 \text { (C. salmonicola) } \\
\text { AJ } 14286 \text { (C. tropicalis var. lambica) } \\
\text { AJ } 4797 \\
\text { J } 1017 \\
\text { J } 1012\end{array}$ & $\begin{array}{l}\text { IFO } 0650 \\
\text { CBS } 2921 \\
\text { CBS } 5690 \\
\text { CBS } 617 \\
\text { Mushroom } \\
\text { ATCC } 7349 \\
\text { ATCC } 10259\end{array}$ \\
\hline II & $\begin{array}{l}\text { C. sake } \\
\text { C. sake } \\
\text { C. subtropicalis }\end{array}$ & $\begin{array}{l}\text { AJ } 4718 \text { (C. maltosa) } \\
\text { AJ } 4719 \text { (C. cloacae }) \\
\text { AJ } 4476\end{array}$ & $\begin{array}{l}\text { CBS } 5611 \\
\text { CBS } 5612 \\
\text { Air YO-146 }\end{array}$ \\
\hline III & $\begin{array}{l}\text { C. sake } \\
\text { C.sake } \\
\text { C.sake } \\
\text { C. sake } \\
\text { C. sake } \\
\text { C. sake } \\
\text { S. cerevisiae } \\
\text { C. parapsilosis }\end{array}$ & $\begin{array}{l}\text { AJ } 4609 \text { (C. parapsilosis var. intermedia) } \\
\text { AJ } 4601 \\
\text { AJ } 4612 \\
\text { AJ } 4615 \\
\text { AJ } 4783 \\
\text { AJ } 4786 \\
\text { J } 6001 \\
\text { J } 1015\end{array}$ & $\begin{array}{l}\text { IFO } 1021 \\
\text { Butter-bur } \\
\text { Melon } \\
\text { Apple } \\
\text { Amino acid factory } \\
\text { Apple } \\
\text { IFO } 0209 \\
\text { ATCC } 10232\end{array}$ \\
\hline IV & $\begin{array}{l}\text { C. sake } \\
\text { C. sake }\end{array}$ & $\begin{array}{l}\text { AJ } 4772 \text { (C. natalensis) } \\
\text { AJ } 4616\end{array}$ & $\begin{array}{l}\text { CCY 29-44-1 } \\
\text { Strawberry }\end{array}$ \\
\hline
\end{tabular}

${ }^{a}$ Central Research Laboratories, Ajinomoto Co., Inc., Kawasaki, Japan.

- Type strain.

${ }^{c}$ Related species.

which sodium 2,2-dimethyl-2-silapentane-5-sulfonate was employed as the internal standard.

Serological characteristics. Serological characteristics of the strains were investigated by slide agglutination tests with factor sera or absorbed antisera and by agar gel diffusion tests with nonabsorbed antisera. Antisera for strains were prepared by the method of Tsuchiya et al. (21) with a slight modification. Rabbits were immunized with heat-killed cells suspended in formalinized saline solution at a concentration equivalent to McFarland scale no. 9. Rabbits were given intravenous injections with cell suspensions of $0.5,1.0,2.0,4.0,4.0$, and $4.0 \mathrm{ml}$ at 3-day intervals. The factor sera of $1,4,5,6,8,9,11,13$, and 34 , which were prepared by the method of Fukazawa et al. (5) for the diagnosis of medically important yeasts, were obtained from IATRON Laboratory (Tokyo); several other factor sera were prepared by the method of Tsuchiya et al. $(21,23)$.

Agar gel diffusion test. Precipitation reactions were performed by the gel diffusion method with $0.85 \%$ Noble agar (Difco) in borate buffer, $\mathrm{pH} 8.4$ (3). Samples of $0.17 \mathrm{ml}(100 \mu \mathrm{g} / \mathrm{ml})$ of purified polysaccharide and undiluted antiserum were placed in the outer and center wells, respectively.

Fluorescent-antibody test. An indirect fluorescent-antibody technique was used only for strains that were spontaneously agglutinated with physiological saline solution. Yeast cells fixed by heat on the slide were first reacted with a drop of factor serum at room temperature for $45 \mathrm{~min}$ in a moist chamber. After the smear was washed with phosphate-buffered saline, it was reacted at room temperature for $45 \mathrm{~min}$ in a moist chamber with a drop of fluorescein isothiocyanate-labeled swine immunoglobulin against rabbit immunoglobulin G (DAKOPATTS, Denmark) diluted 1:8 with phosphate-buffered saline. The slides were then mounted in phosphate-buffered saline containing $50 \%$ glycerol. The stained preparations were examined with a Nikon fluorescent microscope (Nippon Kogaku Co., Tokyo). A positive reaction was determined by comparison with control samples.

\section{RESULTS}

Biological characteristics. The patterns of assimilation and fermentation of carbon compounds by 15 strains of $C$. sake are shown in Table 2. The characteristics of these strains agreed quite well with their standard descriptions.

PMR spectra of polysaccharides. Fifteen strains of $C$. sake were divided into four groups (group I to group IV) on the basis of the patternographic types of the PMR spectra of their mannans in the $\mathrm{H}-1$ region (Table 3 ). The first group comprised five strains including one derived from the type strain of $C$. sake (AJ 5146). The PMR spectra of mannans of these strains classed as type I were characterized by five main signals at $\tau 4.70$ to $4.71, \tau 4.80$ to 4.82 , $\tau 4.88$ to $4.89, \tau 5.03$ to 5.05 , and $\tau 5.11$ to 5.12 . However, three subtypes (i.e., Ia, Ib, and Ic) could be subclassified by more detailed analysis (Fig. 1). 


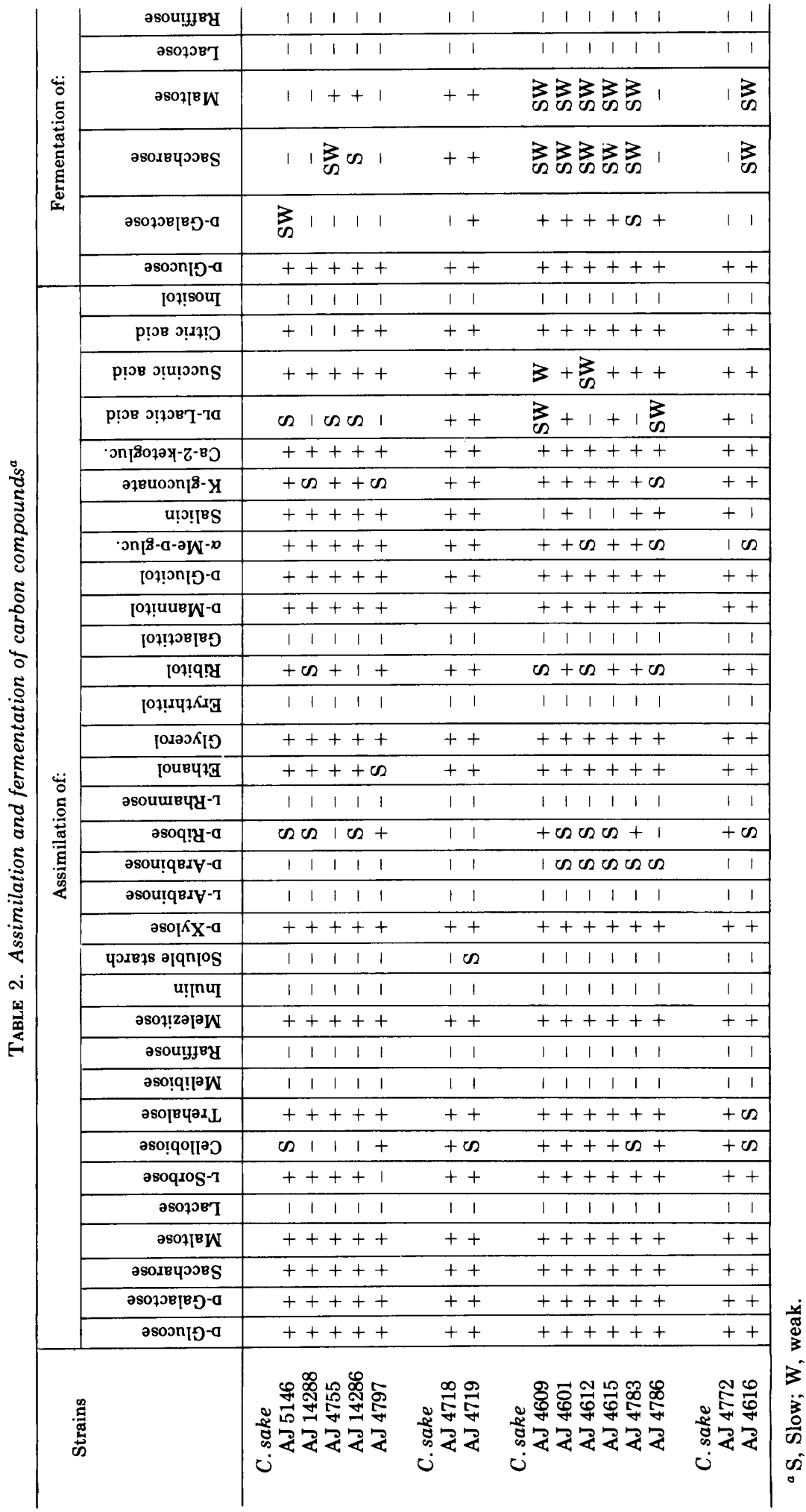


TABLE 3. PMR signals from mannans of $C$. sake and related species

\begin{tabular}{|c|c|c|c|c|c|c|c|c|}
\hline \multirow{3}{*}{$\begin{array}{l}\text { Group } \\
\text { I }\end{array}$} & \multirow{2}{*}{\multicolumn{2}{|c|}{ Strains }} & \multicolumn{6}{|c|}{ Signals $(\tau)$} \\
\hline & & & \multirow{2}{*}{$\frac{\mathrm{A}}{4.70}$} & \multirow{2}{*}{$\frac{B}{4.80}$} & \multirow{2}{*}{$\begin{array}{c}\mathrm{C} \\
4.88\end{array}$} & \multirow{2}{*}{$\frac{D}{5.03}$} & \multirow{2}{*}{$\begin{array}{c}\mathrm{E} \\
5.11\end{array}$} & $F$ \\
\hline & C. sake & AJ 5146 & & & & & & \\
\hline & C. sake & AJ 14288 & 4.71 & 4.81 & 4.89 & 5.04 & 5.12 & \\
\hline & C. sake & AJ 4755 & 4.70 & 4.80 & 4.88 & 5.03 & 5.11 & \\
\hline & C. sake & AJ 14286 & 4.71 & 4.81 & 4.89 & 5.05 & 5.12 & \\
\hline & C. sake & AJ 4797 & 4.70 & 4.80 & 4.89 & 5.04 & 5.11 & \\
\hline & C. tropicalis & J 1017 & 4.71 & 4.82 & 4.90 & 5.05 & 5.12 & \\
\hline & C.albicans & J 1012 & 4.70 & 4.80 & 4.89 & 5.03 & 5.11 & 5.18 \\
\hline \multirow[t]{3}{*}{ II } & C.sake & AJ 4718 & 4.71 & & 4.91 & 5.05 & 5.11 & \\
\hline & C. sake & AJ 4719 & 4.71 & & 4.90 & 5.03 & 5.10 & \\
\hline & C. subtropicalis & AJ 4476 & 4.71 & & 4.90 & 5.02 & 5.10 & \\
\hline \multirow[t]{7}{*}{ III } & C. sake & AJ 4609 & 4.70 & 4.81 & 4.90 & & & \\
\hline & C. sake & AJ 4601 & 4.73 & 4.82 & 4.91 & & & \\
\hline & C.sake & AJ 4612 & 4.70 & 4.81 & 4.90 & & & \\
\hline & C.sake & AJ 4615 & 4.71 & 4.82 & 4.91 & & & \\
\hline & C.sake & AJ 4783 & 4.71 & 4.82 & 4.91 & & & \\
\hline & C. sake & AJ 4786 & 4.71 & 4.82 & 4.91 & & & \\
\hline & S. cerevisiae & J 6001 & 4.71 & 4.82 & 4.91 & & & \\
\hline \multirow[t]{2}{*}{ IV } & C. sake & AJ 4772 & 4.69 & 4.80 & 4.89 & 5.02 & & \\
\hline & C.sake & AJ 4616 & 4.70 & 4.80 & 4.89 & 5.01 & & \\
\hline
\end{tabular}

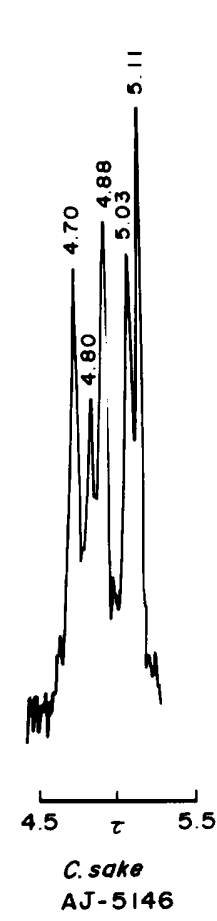

1 a

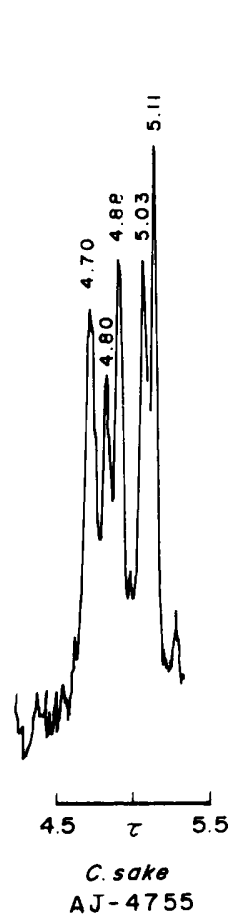

I a

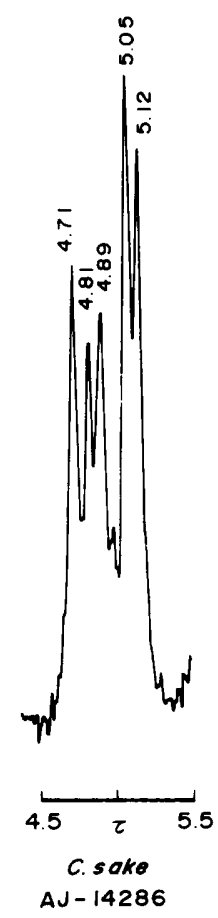

Ib

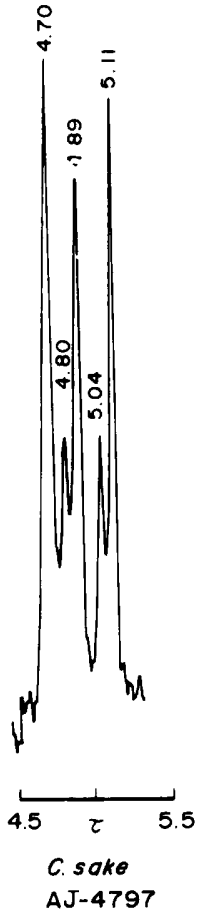

Ic

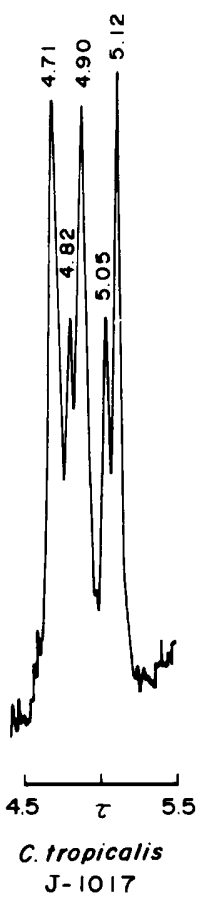

$1 \mathbf{a}$

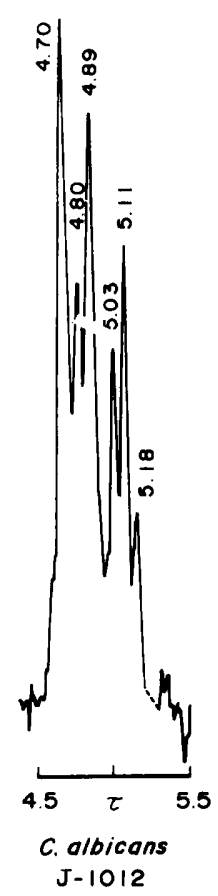

I c

Fig. 1. PMR spectra (H-1 region) of mannans from group I strains of $C$. sake and related species. Arabic numerals indicate chemical shift of each signal. 
Type I strains included C. albicans serotype $A$ and $C$. tropicalis, and the PMR spectrum of mannan of the type strain of C. sake (AJ 5146) was found to be very similar to that of $C$. tropicalis.

The second group consisted of two strains of C. sake and one strain of C. subtropicalis (Table 3). The PMR spectra of mannans of type II strains were nearly identical (Fig. 2). The PMR spectra of mannans of this group were characterized by four main signals at $\tau 4.71, \tau 4.90$ to $4.91, \tau 5.02$ to 5.05 , and $\tau 5.10$ to 5.11 .

The third group comprised six strains of $C$. sake and one of $S$. cerevisiae (Table 3 ). The PMR spectra of mannans of this group were characterized by three main signals at $\tau 4.70$ to $4.73, \tau 4.81$ to 4.82 , and $\tau 4.90$ to 4.91 (Fig. 3).

The fourth group included two $C$. sake strains. The PMR spectra of mannans of this group were characterized by four signals at $\tau$ 4.69 to $4.70, \tau 4.80, \tau 4.89$, and $\tau 5.01$ to 5.02 (Table 3). The most prominent signal was at $\tau$ 4.89 , and the intensity of signal 4 differed markedly between the two strains (Fig. 4).

Serological characteristics. (i) Agar gel diffusion tests. The specificity of mannans of each group of $C$. sake was examined by the gel diffusion precipitation test with antiserum for

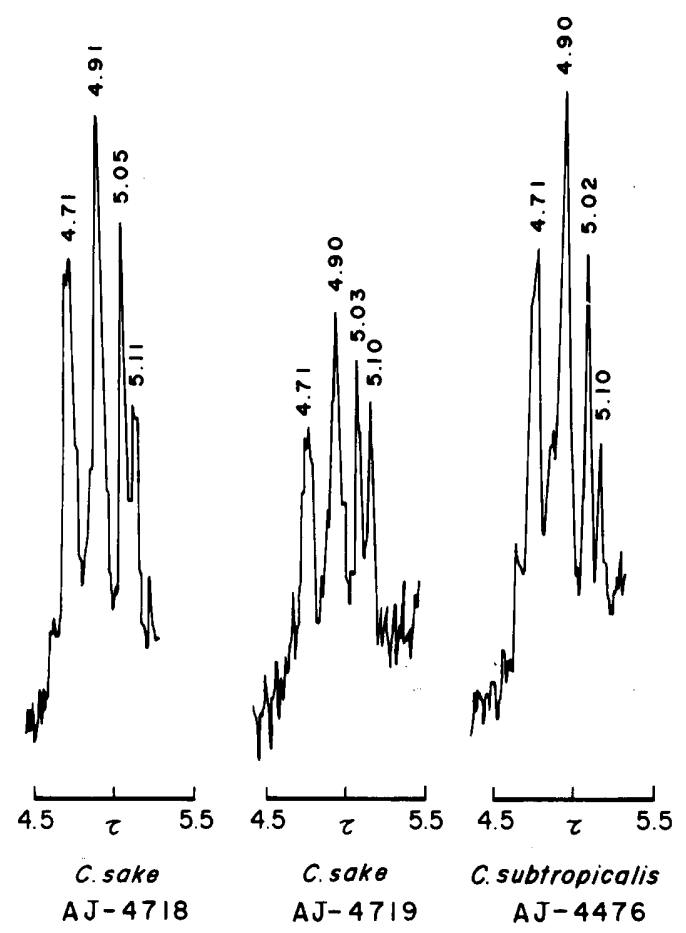

FIG. 2. PMR spectra (H-1 region) of mannans from group II strains of C. sake. the reference strain of each group (Fig. 5). Antiserum for C. sake (AJ 5146) was placed in the center well, and mannans of groups I (AJ 5146), II (AJ 4718), III (AJ 4609), and IV (AJ 4616) and C. albicans were placed in the outer wells. The mannans of strains belonging to group I and of $C$. albicans formed identical precipitin bands against anti-C. sake (AJ 5146). In contrast, mannans of strains belonging to groups II and III formed precipitin bands that were not identical to each other or to mannans of group I. Mannan of the group IV strain AJ 4616 did not show any precipitin band against the above antiserum (Fig. 5A). These results indicate that the immunochemical structures of mannans of group I and of C. albicans are nearly identical, and mannans of groups II and III are partially different from those of group I; mannan of group IV is not serologically related to that of group I. Subsequently, antiserum prepared against a strain of group IV was placed in the center well and mannans of groups I, II, III, and IV, S. cerevisiae and C. parapsilosis were placed in the outer wells (Fig. 5B). The precipitin band for the mannan of group IV formed a spur upon meeting the precipitin bands for group III and S. cerevisiae, indicating nonidentical serological cross-reactions. In contrast, mannans of groups I and II and of C. parapsilosis (J 1015) did not form precipitin bands against antiserum to the strain of group IV. The results indicate that the mannan of group IV is serologically related to those of group III and S. cerevisiae but not to those of groups I and II.

(ii) Slide agglutination tests for whole cells. The antigenic patterns of members of $C$. sake were examined by slide agglutination tests with 10 different factor sera. The members of group I demonstrated antigens 1, 4, 5, and 6 . Strains of the second group (AJ 4718 and AJ 4719) demonstrated antigens 1,4 , and 5 . The members of group III were found to possess antigens 1,13 , and 18 but not antigens 4 and 6 .

Members of group IV possessed antigens 1 and 18 but not antigens 4,6 , or 13 (Table 4). The results suggest that antigenic patterns of the strains of group I and II are very similar to those of $C$. albicans or $C$. tropicalis and $C$. subtropicalis, respectively, and that antigenic patterns of the strains of group IV are closely related to those of $S$. cerevisiae. Furthermore, it is suggested that antigenic patterns of members of group III are related to those of both $C$. parapsilosis and S. cerevisiae. Serological relationships among strains of groups III and IV, $S$. cerevisiae, and $C$. parapsilosis were examined by reciprocal absorption experiments (Table 5). 

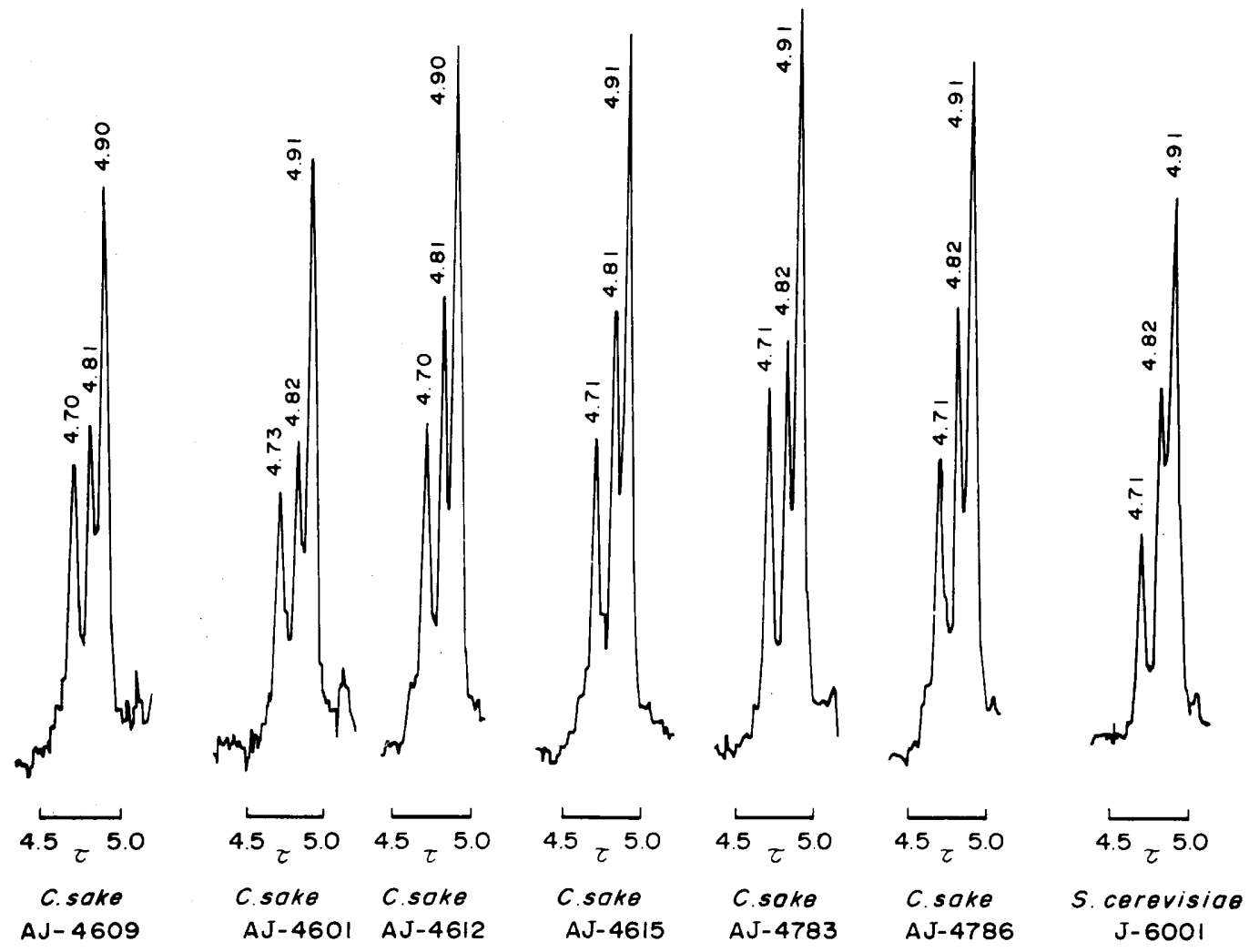

FIG. 3. PMR spectra (H-1 region) of mannans from group III strains of $C$. sake and related species.

Experiment 1 shows that when antiserum for $S$. cerevisiae was absorbed successively with heated cells of $C$. albicans, C. parapsilosis, and C. pseudotropicalis the absorbed serum reacted with antigens of $S$. cerevisiae, C. sake (AJ 4609), and $C$. sake (AJ 4616). These reactions may be attributable to antigenic factor 18 that is shared by these three strains but is absent in the former three strains. Experiment 2 shows that the antiserum for $S$. cerevisiae absorbed with $C$. sake (AJ 4609, group III) reacted only with the antigen of $S$. cerevisiae. This factor was tentatively designated as antigen $18 \mathrm{~b}$. Antiserum for $S$. cerevisiae absorbed with $C$. sake (AJ 4616, group IV) demonstrated positive reactions to $S$. cerevisiae, C. sake (AJ 4609, group III), and C. parapsilosis (experiment 3 ). These reactions may be due to antigen $18 \mathrm{~b}$ and some other unknown partial antigens. Experiment 4 shows that antiserum to $C$. sake (AJ 4616, group IV) absorbed with $S$. cerevisiae reacted only with the homologous strain. This factor was tentatively designated as 18c. Experiments 6 and 7 show that antiserum to $C$. sake (AJ 4609, group III) absorbed either with $S$. cerevisiae or C. sake
(AJ 4616, group IV) reacted with antigens of $C$. parapsilosis and C. sake (AJ 4609, group III). The antigenic factor 13 may be responsible for the reactions noted in experiments 6 and 7 .

$\dot{G}+\mathbf{C}$ content of DNA. The $\mathrm{G}+\mathrm{C}$ contents of 15 members of $C$. sake and related species were calculated from DNA preparations exhibiting monophasic temperature-absorbance profiles (Table 6). Strains are listed by the mannan serological groupings described above. The first group demonstrated a $\mathrm{G}+\mathrm{C}$ content of 36.8 to $41.2 \mathrm{~mol} \%$, although the PMR spectra of mannan, the agar gel diffusion patterns, and the antigenic structures in this group were very closely related to each other. In the second group, $\mathrm{G}+\mathrm{C}$ contents of two strains of $C$. sake AJ 4718 (C. maltosa) and AJ 4719 (C. cloacae), were found to be 36.3 and $39.5 \mathrm{~mol} \%$, respectively, and that of $C$. subtropicalis was almost the same as that of $C$. sake AJ 4718 (C. maltosa).

On the other hand, the $\mathrm{G}+\mathrm{C}$ content of the strains of the third group demonstrated a higher value than those of the above-mentioned two groups. The range of the $\mathrm{G}+\mathrm{C}$ content of this 


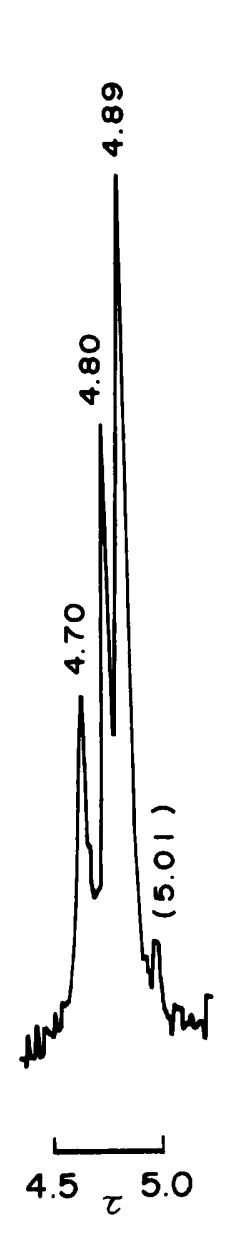

\section{C. soke}

AJ- 4772

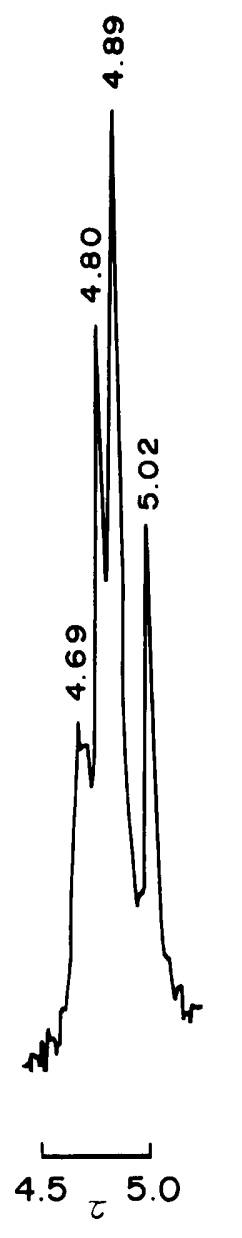

\section{C.sake} AJ- 4616

FIG. 4. PMR spectra (H-1 region) of mannans from group IV strains of C. sake.

group was 41.0 to $42.2 \mathrm{~mol} \%$, and those of $C$. parapsilosis and $S$. cerevisiae were found to be fairly similar to those of this group, showing values close to $40 \mathrm{~mol} \%$.

The two strains of the fourth group demonstrated similar $\mathrm{G}+\mathrm{C}$ contents (36.6 and 36.8 $\mathrm{mol} \%$ ).

The antigenic structures, the type of PMR spectra, and $\mathrm{G}+\mathrm{C}$ contents of strains of $C$. sake and related species are summarized in Table 7.

\section{DISCUSSION}

According to the recent work of van Uden et al. which appeared in the monograph on yeast taxonomy (8), several species of Candida are

gathered into one species, $C$. sake (Saito et al.) van Uden et Buckley nov.comb. The reason for this unification into one species is not clear. The significance of PMR spectra of the mannans of the yeast cell wall for taxonomic studies and the correlation between PMR spectra and chemical structures of side-chain groups of polysaccharides have been investigated in detail and summarized by Gorin and Spencer (7). The pattern analyses for the PMR spectra of cell wall mannans of eight strains of $C$. sake, including the previous taxa $T$. sake, C. maltosa, $C$. parapsilosis var. intermedia, C. natalensis, $C$. cloacae, and C. salmonicola, have indicated that these strains could be divided into four types
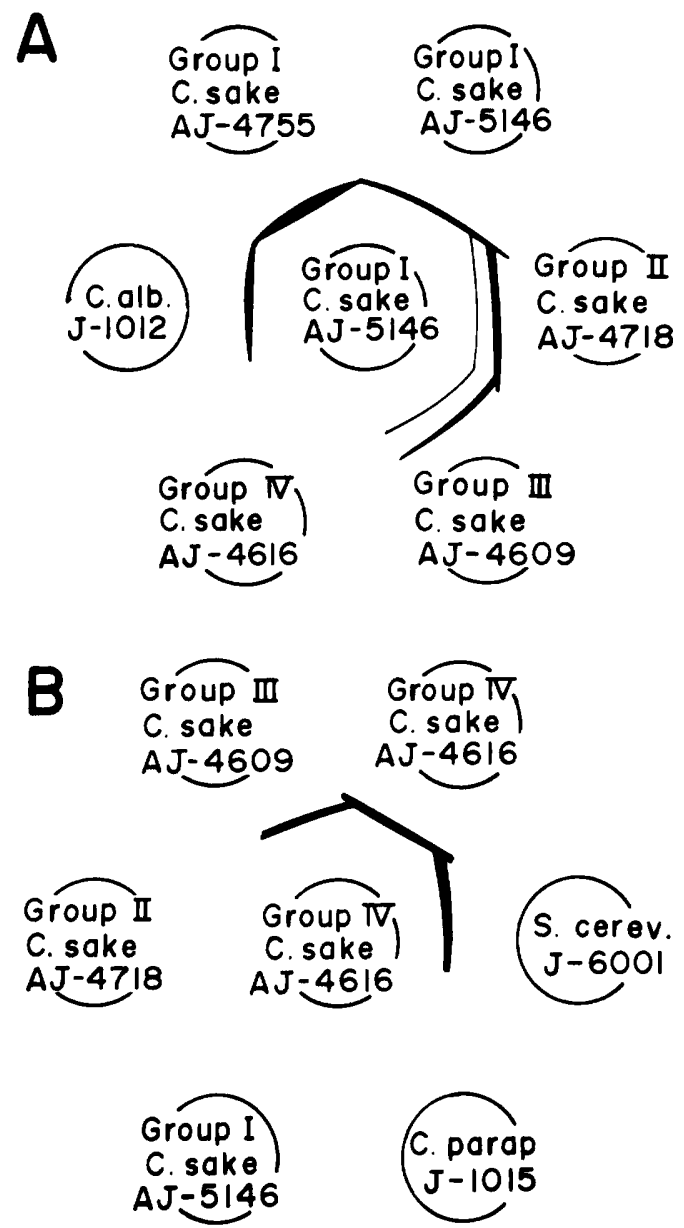

FIG. 5. Schematic illustrations of agar gel diffusion tests with mannans from strains of each group of $C$. sake and related species. (A) Anti-C. sake AJ 5146 antiserum was placed in the center well. (B) Anti-C. sake AJ 4616 antiserum was placed in the center well. Antigens were placed in the outer wells in each case. 
TABLE 4. Slide agglutination against factor sera

\begin{tabular}{|c|c|c|c|c|c|c|c|c|c|c|c|c|}
\hline \multirow{2}{*}{ Group } & \multirow{2}{*}{\multicolumn{2}{|c|}{ Heat-killed cells }} & \multicolumn{10}{|c|}{ Slide agglutination with factor sera ${ }^{a}$} \\
\hline & & & 1 & 4 & 5 & 6 & 8 & 9 & 11 & 13 & 18 & 34 \\
\hline \multirow[t]{7}{*}{ I } & C.sake & AJ 5146 & + & + & + & + & - & - & - & - & - & - \\
\hline & C.sake & AJ 14288 & + & + & + & + & - & - & - & - & - & - \\
\hline & C. sake & AJ 4755 & + & + & + & + & - & - & - & - & - & - \\
\hline & C. sake & AJ 14286 & + & + & + & + & - & - & - & - & - & - \\
\hline & C. sake & AJ 4797 & + & + & + & + & - & - & - & - & - & - \\
\hline & C. tropicalis & J 1017 & + & + & + & + & - & - & - & - & - & - \\
\hline & C. albicans & J 1012 & + & + & + & + & - & - & - & - & - & - \\
\hline \multirow[t]{3}{*}{ ПI } & C. sake & AJ 4718 & + & + & + & - & - & - & - & - & - & - \\
\hline & C. sake & AJ 4719 & + & + & + & - & - & - & - & - & - & - \\
\hline & C. subtropicalis & AJ 4476 & + & + & + & - & - & - & - & - & - & - \\
\hline \multirow[t]{8}{*}{ III } & C. sake & AJ 4609 & + & - & - & - & - & - & - & + & + & - \\
\hline & C. sake & AJ 4601 & + & - & $(+)$ & - & - & - & - & + & + & - \\
\hline & C. sake & AJ 4612 & + & - & - & - & - & - & - & + & + & - \\
\hline & C.sake & AJ 4615 & + & - & $(+)$ & - & - & & - & + & + & - \\
\hline & C. sake & AJ 4783 & + & - & - & - & - & - & - & + & + & - \\
\hline & C. sake & AJ 4786 & + & - & - & - & - & - & - & $(+)$ & + & - \\
\hline & S. cerevisiae & J 6001 & + & - & - & - & - & - & - & - & + & - \\
\hline & C. parapsilosis & J 1015 & + & - & + & - & - & - & - & + & - & - \\
\hline \multirow[t]{2}{*}{ IV } & C. sake & AJ 4772 & + & - & - & - & - & - & - & - & + & - \\
\hline & C. sake & AJ 4616 & + & - & - & - & - & - & - & - & + & - \\
\hline
\end{tabular}

${ }^{a}+$, Positive agglutination; $(+)$, weakly positive agglutination; - , negative agglutination.

TABLE 5. Absorption experiments for strains of groups III and IV

\begin{tabular}{|c|c|c|c|c|c|c|c|}
\hline \multirow[b]{2}{*}{ Exp no. } & \multirow[b]{2}{*}{ Antisera for: } & \multirow{2}{*}{ Absorption with: } & \multicolumn{4}{|c|}{ Slide agglutination with: ${ }^{a}$} & \multirow{2}{*}{$\begin{array}{l}\text { Antibody } \\
\text { factors } \\
\text { remaining }\end{array}$} \\
\hline & & & $\begin{array}{l}\text { C. para- } \\
\text { psilosis }\end{array}$ & $\begin{array}{l}\text { C. sake } \\
\text { AJ } 4609\end{array}$ & $\begin{array}{l}\text { C. sake } \\
\text { AJ } 4616\end{array}$ & $\begin{array}{c}S . \\
\text { cerevisiae }\end{array}$ & \\
\hline 1 & S. cerevisiae & $\begin{array}{l}\text { C. albicans + C. para- } \\
\text { psilosis }+ \text { C.pseudo- } \\
\text { tropicalis }\end{array}$ & - & + & + & + & 18 \\
\hline 2 & S. cerevisiae & C.sake (G-III) & - & - & - & + & $18 \mathrm{~b}$ \\
\hline 3 & S. cerevisiae & $\begin{array}{l}\text { C. sake }(\mathrm{G}-\mathrm{IV})+ \\
\text { C. sake }(\mathrm{G}-\mathrm{III})\end{array}$ & $\begin{array}{l}+ \\
-\end{array}$ & $\begin{array}{l}+ \\
-\end{array}$ & - & $\begin{array}{l}+ \\
+\end{array}$ & $\begin{array}{l}18 b . \\
18 b\end{array}$ \\
\hline 4 & C. sake (G-IV) & S. cerevisiae & - & - & + & - & $18 \mathrm{c}$ \\
\hline 5 & C. sake (G-IV) & C.sake (G-III) & - & - & + & - & $18 \mathrm{c}$ \\
\hline 6 & C.sake (G-III) & S. cerevisiae & + & + & - & - & 13 \\
\hline 7 & C.sake (G-III) & C. sake (G-IV) & + & + & - & - & 13 \\
\hline
\end{tabular}

${ }^{a}+$, Positive agglutination; -, negative agglutination.

(12). In the present study, mannans of 15 strains of $C$. sake, including another previous taxon of $C$. vanriji, $C$. tropicalis var. lambica, several isolates and four strains of related species were examined for their PMR spectra in comparative experiments and found to be included in the same four types (Table 7). Strains of type I form mannans whose spectra are closely related to each other and are characterized by five signals. These strains could be divided further into three subtypes, $1 \mathrm{a}, 1 \mathrm{~b}$, and $1 \mathrm{c}$, based on the prominent signals of $\tau 5.11, \tau 5.05$, and $\tau 4.70$, 
TABLE 6. $G+C$ content in DNA of strains of $C$. sake and related species.

\begin{tabular}{|c|c|c|c|c|}
\hline Group & \multicolumn{2}{|c|}{ Strains } & $T_{m}(\mathrm{C})$ & $\underset{(\mathrm{mol} \%)}{\mathrm{G}+\mathrm{C} \text { content }}$ \\
\hline I & $\begin{array}{l}\text { C. sake } \\
\text { C. sake } \\
\text { C. sake } \\
\text { C. sake } \\
\text { C. sake } \\
\text { C.tropicalis } \\
\text { C. albicans }\end{array}$ & $\begin{array}{c}\text { AJ } 5146 \\
\text { AJ } 14288 \\
\text { AJ } 4755 \\
\text { AJ } 14286 \\
\text { AJ } 4797 \\
\text { J } 1017 \\
\text { J } 1012\end{array}$ & $\begin{array}{l}85.2 \\
86.0 \\
85.6 \\
86.2 \\
84.4 \\
83.3 \\
83.4\end{array}$ & \begin{tabular}{l|}
38.8 \\
40.7 \\
39.8 \\
41.2 \\
36.8 \\
34.1 \\
34.4
\end{tabular} \\
\hline II & $\begin{array}{l}\text { C. sake } \\
\text { C. sake } \\
\text { C. subtropicalis }\end{array}$ & $\begin{array}{l}\text { AJ } 4718 \\
\text { AJ } 4719 \\
\text { AJ } 4476\end{array}$ & $\begin{array}{l}84.2 \\
85.5 \\
84.3\end{array}$ & $\begin{array}{l}36.3 \\
39.5 \\
36.6\end{array}$ \\
\hline III & $\begin{array}{l}\text { C.sake } \\
\text { C.sake } \\
\text { C.sake } \\
\text { C.sake } \\
\text { C.sake } \\
\text { C.sake } \\
\text { S. cerevisiae } \\
\text { C.parapsilosis }\end{array}$ & $\begin{array}{l}\text { AJ } 4609 \\
\text { AJ } 4601 \\
\text { AJ } 4612 \\
\text { AJ } 4615 \\
\text { AJ } 4783 \\
\text { AJ } 4786 \\
\text { J } 6001 \\
\text { J } 1015\end{array}$ & $\begin{array}{l}86.1 \\
86.6 \\
85.9 \\
86.5 \\
86.5 \\
86.5 \\
85.5 \\
85.5\end{array}$ & $\begin{array}{l}41.0 \\
42.2 \\
40.5 \\
42.0 \\
42.0 \\
42.0 \\
39.5 \\
39.5\end{array}$ \\
\hline IV & $\begin{array}{l}\text { C. sake } \\
\text { C. sake }\end{array}$ & $\begin{array}{l}\text { AJ } 4772 \\
\text { AJ } 4616\end{array}$ & $\begin{array}{l}84.4 \\
84.3\end{array}$ & $\begin{array}{l}36.8 \\
36.6\end{array}$ \\
\hline
\end{tabular}

TABLE 7. Heterogeneous characteristics of C. sake

\begin{tabular}{|c|c|c|c|c|}
\hline Determination & Group I & Group II & Group III & Group IV \\
\hline $\begin{array}{l}\text { Antigenic } \\
\text { structure }\end{array}$ & $1,4,5,6 \ldots$ & $1,4,5 \ldots$ & $1,13,18 \ldots$ & $1,18,18 \mathrm{c} \ldots$ \\
\hline $\begin{array}{l}\text { Type of PMR } \\
\text { spectrum }\end{array}$ & 1 & 2 & 3 & 4 \\
\hline $\mathrm{G}+\mathrm{C}$ content & $37-41 \mathrm{~mol} \%$ & $36-40 \mathrm{~mol} \%$ & $41-42 \mathrm{~mol} \%$ & $37 \mathrm{~mol} \%$ \\
\hline C. sake (1970) & $\begin{array}{l}\text { AJ } 5146,39 \% 1 \mathrm{a} \\
\text { AJ } 14288,41 \% 1 \mathrm{a} \\
\text { AJ } 4755,40 \% 1 \mathrm{a} \\
\text { AJ } 14286,41 \% 1 \mathrm{~b} \\
\text { AJ } 4797,37 \% 1 \mathrm{c}\end{array}$ & $\begin{array}{l}\text { AJ } 4718,36 \% \\
\text { AJ } 4719,40 \%\end{array}$ & $\begin{array}{l}\text { AJ } 4609,41 \% \\
5 \text { additional isolates }\end{array}$ & $\begin{array}{l}\text { AJ } 4772,37 \% \\
\text { AJ } 4616,37 \%\end{array}$ \\
\hline Related species & $\begin{array}{l}\text { C. tropicalis J } 1017 \text {, } \\
34 \% \text { 1a } \\
\text { C. albicans J 1012, } \\
34 \% \text { 1c }\end{array}$ & $\begin{array}{l}\text { C. subtropicalis AJ } \\
\quad 4476,37 \%\end{array}$ & $\begin{array}{l}\text { S. cerevisiae J } 6001, \\
40 \% \\
1,18,18 \mathrm{~b} \ldots \\
\\
\text { C. parapsilosis } \mathrm{J} 1015, \\
40 \% \\
1,5,13 \ldots\end{array}$ & $\begin{array}{l}\text { S. cerevisiae J } 6001 \text {, } \\
\quad 40 \% \\
1,18,18 \mathrm{~b} \ldots\end{array}$ \\
\hline
\end{tabular}

respectively. Strains of type II form mannans whose spectra closely resemble each other, characterized by four signals. Strains of type III and type IV form mannans whose spectra are closely related to each other and are characterized by three and four signals, respectively, showing a prominent signal at $\tau 4.90$. PMR spectra of a strain of AJ-4772 was almost identical to those of group III strains. Serologically, however, this strain was not reacted with factor 13 , but reacted with factor 18 . Therefore, this strain was tentatively placed in group IV. Further immunochemical analyses of this strain remain to be done. It must be noted that PMR spectra of mannans measured by us were always shifted to a higher field of about $\tau 0.5$ in comparison 
with those observed by Gorin and Spencer (7). The reason for these differences in shifts may be due to a difference between the external and internal standards employed.

The terminal groups of the side chain of polysaccharides of microorganisms have been shown to be responsible for serological specificity $(1,9,20)$. However, the chemical basis of the immunological cross-reactions of mannans of different yeasts have been elucidated only in the limited structures of determinants. In addition to the defined chemical structures, the mode of responding action of antibody classes to recognize the range of terminal groups in the side chains has not yet been clarified. Therefore, the serological methodology may still provide a more general profile of the surface structures of the cell wall. Here we show that serological studies on 15 strains of $C$. sake also divide the strains into four serogroups and that these groups correspond to the PMR spectra of mannans (Table 7). Serological analyses by the slide agglutination test with factor sera and absorbed sera further indicated that antigenic patterns of groups I and II related closely to those of $C$. tropicalis and C. subtropicalis (13), respectively. Strains of group III have antigens 13 and 18 , which are specific for $C$. parapsilosis and $S$. cerevisiae, respectively, although PMR spectra of mannans of this group are not much like those of $C$. parapsilosis. The antigenic pattern of group IV is closely related to that of $S$. cerevisiae. These observations may suggest that antigenic patterns are highly significant markers for the demonstration of phylogenetic relationships among yeast species. A conception of Gorin and Spencer (7), that the structures of the cell wall mannose-containing polysaccharides of yeasts are not readily susceptible to change, may support our emphasis.

Phaff et al. (17) indicated that members of $C$. sake can be divided into a number of physiological variants. However, we found that in ability to assimilate and ferment various carbon compounds members of $C$. sake were fairly close to each other, although not identical. Barnett (2) gave several examples of linked mechanism whereby yeasts that use one substrate can also use a structurally related one by the same metabolic pathway. Gorin and Spencer (7) noted that probably only minor differences in carbohydrate metabolism are concerned in these tests because various carbon compounds are not necessarily assimilated independently but may be metabolized by common pathways.

The base composition of DNA is considered to be one of the most useful criteria for the classification of microorganisms. This has been clearly shown first in the field of bacteria (4) and later in the field of yeast taxonomy $(11,12$, $18,19)$. In the present studies, the $G+C$ values of strains of $C$. sake assigned to group I were distributed in a rather wide range from approximately 37 to $41 \mathrm{~mol} \%$. The $\mathrm{G}+\mathrm{C}$ values of $C$. albicans and $C$. tropicalis, whose serological properties and PMR spectra of mannans resemble those of members of group I, are found to be rather lower (Table 7). The significance of the heterogeneity in the $\mathrm{G}+\mathrm{C}$ contents among strains of groups I and II remain to be studied. In these cases, hybridization studies must be done to establish genetic homology in addition to comparison of $\mathrm{G}+\mathrm{C}$ contents of the strains. However, strains assigned to groups III and IV have $\mathrm{G}+\mathrm{C}$ values with narrow ranges within each group (Table 7). Recently, Gorin and Spencer (7) suggested that chemical structures of macromolecules of the yeast cell, such as the nucleic acids, proteins, and polysaccharides, are new valuable criteria for yeast taxonomy. In bacteria, species or serotype-specific properties have been demonstrated on some organelles, such as the capsule, cell wall, and flagella. Furthermore, it might be assumed that the structures of the cell wall are a most significant criterion for yeast taxonomy since the structures of the outer layer of the cell are believed to be more species, or strain, specific than inner structural components (1). Therefore, antigenic properties and PMR spectra of mannose-containing polysaccharides, which are reflections of the macromolecular structures of the cell wall, should be a primary consideration in yeast classification.

Based on the serological characteristics referring to PMR spectra of mannans, we have reclassified the members of $C$. sake. These results suggest the following taxonomic changes. (i) Species of $C$. sake should be limited to the strains of group I whose antigenic patterns resemble those of $C$. tropicalis. (ii) Strains of group II, whose antigenic patterns are related to those of $C$. subtropicalis, should form an independent species with a species name such as C. maltosa, C. cloacae, or C. subtropicalis. (iii) Strains of group III whose antigenic patterns are related to both $C$. parapsilosis and $S$. cerevisiae should be raised to constitute a new species, and the previous taxon of $C$. parapsilosis var. intermedia should be discarded. (iv) Strains of group IV whose antigenic patterns are related closely to those of $S$. cerevisiae should form an independent species such as $C$. natalensis.

Previously, Tsuchiya et al. (22) have shown that multiple yeast species classified by biologi- 
cal characteristics could be placed together in one species by their antigenic structures, although minor differences in their morphological or biochemical characteristics are shown. This is the first instance that strains of a single species have been divided into multiple species by their antigenic patterns and PMR spectra of mannans. Although characteristics of cell wall structures expressed either serologically or physicochemically are evidently significant in yeast taxonomy, difficulties may occur mainly with respect to the specialized techniques. Among the serological problems, it must be noted that standardized factor sera necessary for the identification of medically important yeasts are now available (as mentioned elsewhere in this report), and it might be expected that additional factor sera necessary for grouping various yeasts will be available in the near future.

Serological properties relating to cell wall structures, especially when supplemented with examination of the PMR spectra of polysaccharides, are a most useful criterion in yeast classification, although these methods are based on parameters that are not chemically defined at present.

\section{ACKNOWLEDGMENTS}

We are very grateful to $P$. E. Hartman for critical reading of the manuscript and to I. Sato for his valuable advice.

\section{REPRINT REQUESTS}

Address reprint requests to: Dr. Y. Fukazawa, Department of Microbiology, Meiji College of Pharmacy, 1-35-23 Nozawa, Setagaya-ku, Tokyo 154, Japan.

\section{LITERATURE CITED}

1. Ballou, C. E., and W. C. Raschke. 1974. Polymorphism of the somatic antigen of yeast. Science 184:127-134.

2. Barnett, J. A. 1974. A new key to the yeasts: a key for identifying yeasts based on physiological tests only. North-Holland Publishing Co., Amsterdam.

3. Carpenter, P. L. 1965. Immunology and serology, p. 425. W. B. Saunders Co., Philadelphia.

4. De Ley, J. 1968. Molecular biology and bacterial phylogeny, p. 103-156. In T. Dobzhansky, M. K. Hecht, and W. G. Steere (ed.), Evolutionary Biology, vol. 2. North-Holland Publishing Co., Amsterdam.

5. Fukazawa, Y., T. Shinoda, and T. Tsuchiya, 1968. Response and specificity of antibodies for Candida albicans. J. Bacteriol. 95:754-763.

6. Gorin, P. A. J., and J. F. T. Spencer. 1968. Galactomannans of Trichosporon fermentans and other yeasts: proton magnetic resonance and chemical studies. Can. J. Chem. 46:2299-2304

7. Gorin, P. A. J., and J. F. T. Spencer. 1970. Proton magnetic resonance spectroscopy: an aid in identifica- tion and chemotaxonomy of yeasts. Adv. Appl. Microbiol. 13:25-89.

8. Lodder, J. (ed). 1971. The yeasts, a taxonomic study, p. 1034-1043. North-Holland Publishing Co., Amsterdam.

9. Lüderitz, O., A. M. Staub, and O. Westphal. 1966. Immunochemistry of $\mathrm{O}$ and $\mathrm{R}$ antigens of Salmonella and related Enterobacteriaceae. Bacteriol. Rev. 30:192-255.

10. Marmur, J., and P. Doty. 1962. Determination of the base composition of DNA from its thermal denaturation temperature. J. Mol. Biol. 5:109-118.

11. Meyer, S. A., and H. J. Phaff. 1969. Deoxyribonucleic acid base composition in yeasts. J. Bacteriol. 97:52-56.

12. Nakase, T. 1972. Significance of DNA base composition in the classification of yeasts and yeast-like fungi, $p$. 785-791. In G. Terui (ed.), Proc. IV international fermentation symposium: fermentation technology today. Society of Fermentation Technology, Japan, Osaka.

13. Nakase, T., Y. Fukazawa, and T. Tsuchiya. 1972. A comparative study on two forms of Candida tropicalis Cast.) Berkhout. J. Gen. Appl. Microbiol. 18:349-363.

14. Nakase, T., and K. Komagata. 1968. Taxonomic significance of base composition of yeast DNA. J. Gen. Appl. Microbiol. 14:345-357.

15. Nakase, T., and K. Komagata. 1971. Significance of DNA base composition in the classification of yeast genus Candida. J. Gen. Appl. Microbiol. 17:259-279.

16. Nakase, T., and K. Komagata. 1971. Significance of DNA base composition in the classification of yeast genus Saccharomyces. J. Gen. Appl. Microbiol. 17:227-238.

17. Phaff, H. J., M. W. Miller, M. Yoneyama, and M. Soneda. 1972. A comparative study of the yeast florae associated with trees on the Japanese Islands and on the west coast of North America, p. 759-774. In G. Terui (ed.), Proc. IV international fermentation symposium: fermentation technology today. Society of Fermentation Technology, Japan, Osaka.

18. Stenderup, A., and A. L. Bak. 1968. Deoxyribonucleic acid base composition of some species within the genus Candida. J. Gen. Microbiol. 52:231-236.

19. Storck, R. 1966. Nucleotide composition of nucleic acid of fungi. II. Deoxyribonucleic acids. J. Bacteriol. 91:227-230.

20. Suzuki, S., H. Sunayama, and T. Saito. 1968. Studies on the antigenic activity of yeasts. I. Analysis of the determinant groups of the mannan of Saccharomyces cerevisiae. Jpn. J. Microbiol. 12:19-24.

21. Tsuchiya, T., Y. Fukazawa, and S. Kawakita. 1959. A method for the rapid identification of the genus Candida. Mycopathol. Mycol. Appl. 10:191-206.

22. Tsuchiya, T., Y. Fukazawa, and S. Kawakita. 1965. Significance of serological studies on yeasts. Mycopathol. Mycol. Appl. 26:1-15.

23. Tsuchiya, T., Y. Fukazawa, M. Taguchi, T. Nakase, and T. Shinoda. 1974. Serologic aspects on yeast classification. Mycopathol. Mycol. Appl. 53:77-92.

24. Wickerham, L. J. 1951. Taxonomy of yeast. U.S. Department of Agriculture technical bulletin no. 1029. U.S. Government Printing Office, Washington, D. C.

25. Yamada, K., and K. Komagata. 1970. Taxonomic studies on coryneform bacteria. III. DNA base composition of coryneform bacteria. J. Gen. Appl. Microbiol. 16: 215-224. 